\title{
Rethinking Probability of Eclectic Approach in the Post-Method Era: A Study for Making English Teaching-Learning Effective in Bangladesh
}

By Md. Khairul Bashar Abstract- For effective English teaching and learning in Bangladesh probability of Eclecticism can be rethought. To do so, the concept of the post-method era is to be implemented. Both Eclecticism and post-method pedagogy put much emphasis on the effectiveness of pedagogy. For a context like Bangladesh, it is very important to formulate culture and context-sensitive need-based pedagogy as there is a lack of effective pedagogy. As the earlier pedagogy failed to produce competent English language users in Bangladesh, it is time to formulate need-based appropriate pedagogy. The present study has been undertaken to consider the existing teaching-learning realities of Bangladesh in the post-method era and suggest effective pedagogy based on the concept of Eclectic Approach.

Definitions of the Key Terms:

Eclecticism: The practice of deriving ideas or styles from a diverse range of sources.

Post method Era: The time after the period of the method.

Pedagogy: The method and practice of teaching. Approach: A particular way of dealing with a problem.

GJHSS-A Classification: FOR Code: 200302

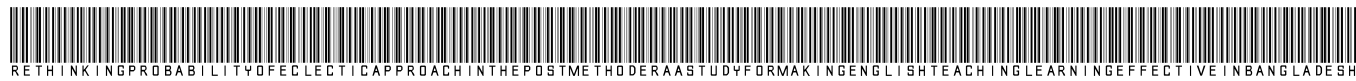

Strictly as per the compliance and regulations of:

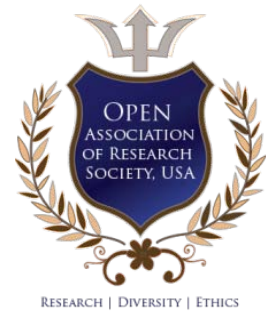

(C) 2020. Md. Khairul Bashar. This is a research/review paper, distributed under the terms of the Creative Commons AttributionNoncommercial 3.0 Unported License http://creativecommons.org/licenses/by-nc/3.0/), permitting all non-commercial use, distribution, and reproduction in any medium, provided the original work is properly cited. 


\title{
Rethinking Probability of Eclectic Approach in the Post-Method Era: A Study for Making English Teaching-Learning Effective in Bangladesh
}

\author{
Md. Khairul Bashar
}

Abstract-For effective English teaching and learning in Bangladesh probability of Eclecticism can be rethought. To do so, the concept of the post-method era is to be implemented. Both Eclecticism and post-method pedagogy put much emphasis on the effectiveness of pedagogy. For a context like Bangladesh, it is very important to formulate culture and context-sensitive need-based pedagogy as there is a lack of effective pedagogy. As the earlier pedagogy failed to produce competent English language users in Bangladesh, it is time to formulate need-based appropriate pedagogy. The present study has been undertaken to consider the existing teachinglearning realities of Bangladesh in the post-method era and suggest effective pedagogy based on the concept of Eclectic Approach.

Definitions of the Key Terms:

Eclecticism: The practice of deriving ideas or styles from a diverse range of sources.

Post method Era: The time after the period of the method.

Pedagogy: The method and practice of teaching.

Approach: A particular way of dealing with a problem.

\section{InTRODUCTION}

clecticism, which combines more than one method in language teaching is expected to fulfill the gap of appropriate pedagogy in Bangladesh. Linguists, educationalists, and scholars now suggest culture and context-sensitive pedagogy as borrowed pedagogy has failed to produce the desired outcome. After many years of teaching-learning, English learners lack the basic skills of English. As a result teachinglearning process become a complete failure. To come out from these shortcomings, language practitioners can follow Eclectic Approach for teaching-learning English in Bangladesh.

\section{a) Statement of the Problem}

For a period, various teaching-learning borrowed pedagogy has been used in Bangladesh. But no one has been able to produce competent English language users. Earlier Grammar Translation Method has been used for a period. Later on, CLT was introduced. After that, a somewhat combination of CLT and GMT is in practice, but after many years of

Author: Lecturer, Sylhet Cadet College, Bangladesh.

e-mail: kbasharnu@gmail.com teaching-learning English, learners remain incompetent. Now it is necessary to rethink the matter of appropriate pedagogy. One single method cannot make language learners communicatively competent in various situations. Learners' needs and purposes for the Bangladeshi context have not been considered while selecting methods.

b) Research Questions

The paper covers the following research questions:

i. Is the present English teaching-learning pedagogy effective?

ii. How can the concepts of Eclecticism be used for a context like Bangladesh?

iii. How can we amalgamate post-method pedagogy and Eclectic Approach for formulating effective pedagogy?

iv. On what basis will Eclectic Approach be conducted?

\section{c) The Objective of the Study}

The main objective of the study is to utilize the concepts of the Eclectic Approach based on the concepts of post-method pedagogy. Pedagogy needs to be formulated based on the present needs of the learners as well as Bangladesh. For that reason, it is important to consider the effectiveness of the existing pedagogy. This paper discusses some important aspects of the eclectic approach, post-method pedagogy, and some well-known language teachinglearning methods and approaches. In the end, it advocates the probability of applying the Eclectic Approach for the context of Bangladesh in the postmethod era.

\section{il. Basic Concepts of Eclecticism}

To explain Eclecticism, language experts and educationalists have defined it in several ways.

According to Rivers (2018), an Eclectic Approach brings opportunities for the teachers to absorb the best techniques of all the well-known language teaching methods into their classroom procedures. The teachers use them for the purposes for which they are most appropriate. It is derived from the concept of combining several theories, styles, and ideas. Similarly, Al-Hamash (1985) says that eclecticism 
chooses different language learning methodologies instead of sticking to standard one. To Larsen- Freeman (2000), "when teachers who subscribe to the pluralistic view of methods pick and choose from among methods to create their blend, their practice is said to be eclectic" (p.183).

In a word, Eclecticism is a pluralistic approach of combining all good ideas, principles, and practices considering the abilities of the learners and the aims of the lesson. It is considered as a methodology of choice where the teachers can select their best culture and context-sensitive procedures for the benefits of their learners. Eclecticism is nothing but a blending of knowledge from all different sources. However, in language education, the eclectic approach is for overcoming the shortcomings of methods.

\section{Literature ReVieW}

The concept of the Eclectic Approach for one's teaching purposes and teaching situations is an earlier one. Language teachers, experts, and educationalists consider this approach as a solution to the ELT problem.

A good method is to be comprehensive and eclectic (Rivers, 1986). Palmer (1964) suggests multiple lines of approach that embody the Eclectic principles allowing teachers the opportunity to choose judiciously. Stern (1983) considers it as a compromise method and a solution to the language teaching method debate. Again Wali (2009) finds that an ELT method cannot meet all the teaching and learning needs. That is why teachers need to adopt a set of techniques as their teaching procedures to fulfill all language goals and program objectives. Furthermore, to implement teaching techniques, a teacher needs to have his teaching style that grabs the students' attention.

Indeed "The successful teacher usually organizes and makes a blend of methods he/ she thinks are appropriate. Each method has its value and uniqueness on one side and its difficulties and an experience of Implementing disadvantages on the other side" (Bell, 2007, p.140-141). Hence, for a variety of language learning activities, Eclecticism is suitable for all types of learners (Kumar, 2013, p.1).

Regarding the post-method era, Bell (2007) argues that methods have limitations that must be overcome. And 'post-method' does not necessarily denote the end of methods rather a desire to go beyond these limitations by allowing more flexibility from teachers.

As a reaction to the ineffectiveness of language teaching methods the eclectic approach of learning was proposed at the beginning of the 1990s and became one of the fashionably popular means for learning English (Kumar, 2013, p.1). Like other approaches and methods, the Eclecticism possesses some principles.
Perhaps, the main aspect of this approach is the opportunity of language teacher to choose suitable methods or techniques befitting the learners' needs and learning situation.

From the literature review, it is very much clear that in an EFL or ESL context like Bangladesh, there is much probability of applying the Eclectic Approach. That is why, there is a scope of research in this sector.

\section{Post-Method Pedagogy}

Key proponents of post-method pedagogy suggest some broad guidelines for designing pedagogy in the post-method era. In his parameter of particularity, Kumaravadivelu (2001, p. 538) proposes that language teaching practices must be sensitive to "a particular group of teachers teaching a particular group of learners pursuing a particular set of goals within a particular institutional context embedded in a particular sociocultural milieu" (p. 538). For successful teaching and learning parameter of particularity is very much significant. Kumavadivelu (1994) also considers 'postmethod condition' as an alternative to a method. Postmethod pedagogy evaluates teaching as a process of creating and utilizing learning opportunities. In his macro strategy of social relevance, Kumaravadivelu (1994) furthermore highlights the need for teachers to be sensitive to the societal political, economic, and educational environment in which language teachinglearning takes place.

Post-method pedagogy welcomes any attempt from the teachers to modify and adjust an established method to the existing realities of local contexts (Richards and Rodgers 2001, p. 251). In this regard, Cattell (2009, p. 59) says, "One way to overcome the limitations of the methods paradigm would be to simply allow teachers to choose from a variety of methods."

In the post-method pedagogy, teachers are to shoulder the responsibilities of formulating their own methods or theories of practice based on local contexts and their experiences.

\section{Existing English Teaching-Learning Condition of Bangladesh}

The history of the ELT pedagogy of Bangladesh is the borrowed one and centered on the GMT method. For a period arena of English language teaching was dominated by the Grammar Translation Method. It was taken as a standard for learning English in Bangladesh. Communication Language Teaching was introduced in 2001 from class six to grade twelve to help the learners to develop their English communicative competence. Because of the enormous class size, lack of inadequacy of logistic supports, teachers' preference of traditional teaching methods, the mismatch between curriculum and assessment, cultural differences, lack of skilled 
teachers, CLT proved as a complete failure. Students cannot communicate in English properly in real-life situations, even after completing twelve years of education. According to the report of the English in Action (EIA) project in 2008-09, students cannot acquire progress beyond the initial level of competence in spoken English even after many years of schooling. Although in recent years, grammar has been reintroduced in school and college curriculum, pedagogy cannot produce competent language users. Thus, one sort of chaotic situation is prevailing in the arena of English language teaching and learning.

\section{Vi. Chief Characteristics of Different Methods and Approaches}

Only Grammar translation and Communication Language Teaching were in practice in Bangladesh, still there are many other methods with own distinctive characteristics for language teaching, which are no less important for the Bangladeshi context.

\section{Grammar Translation Method (GTM):}

With the goal of reading and translating literature GTM was introduced. It:

$>$ applies grammatical rules to translate sentences and texts into and out of the target language.

$>$ focuses on reading and writing.

$>$ encourages deductive grammar (Richards and Rodgers, 2001).

$>$ emphasizes little on spoken language.

$>$ considers accuracy to be essential.

$>$ teaches vocabulary of the target language to reach the goal (Larsen-Freeman, 2004).

$>$ suggests the authoritative rules of teachers in the classroom.

$>$ allows error correction immediately.

Communicative Language Teaching (CLT):

CLT is considered as an approach. It:

$\checkmark$ encourages learning to communicate in the target language for real purposes.

$\checkmark$ also focuses on speaking and listening skills.

$\checkmark$ involves "little grammar instruction" (Sato and Kleinsasser, 1999, p. 502-504).

$\checkmark$ uses authentic materials.

$\checkmark$ promotes the teacher's role as an advisor to establish a situation for communication.

$\checkmark$ suggests pair work and group work.

The Direct Method:

It:

- does not allow translation.

- allows speaking in the target language and communicating in real situations.

- encourages using new words and practising vocabulary in full sentences.

- emphasizes oral communication.

- encourages self-correction.
The Audiolingual Method:

This method:

$>$ advocates a system of reinforcement.

> suggests new words and grammar without using the students' native language.

$>$ does not focus on vocabulary.

$>$ focuses on grammar through drill and practice.

$>$ considers language as verbal behavior and system of habit formation.

The Structural-Situational Approach:

This approach:

- encourages teachers to teach language through a careful selection, gradation, and presentation of vocabulary items and structure through situationbased activities.

- considers speech as the basis of language.

- views structure as the heart of speaking ability.

- considers accuracy as crucial.

Suggestopedia:

It:

> emphasizes learners' mental aspects for removing psychological barriers ( fear, nervousness, tension, frustration, etc.)

$>$ offers a cheerful, bright, colorful, and nonthreatening classroom environment.

The Bilingual Method:

It:

$\checkmark$ means a method of two languages.

$\checkmark$ encourages teaching the language by giving mother tongue equivalents of the words or sentences.

The Total-Physical Response:

It:

- bases on the theory that memory is enhanced through association with a physical response.

- takes structural views of language.

The Silent Way:

It:

$>$ encourages teachers to use a combination of silence and gesture to focus students' attention.

$>$ supports an innovative way of classroom organization.

\section{Vil. Incorporating the Concepts of Post-Method Pedagogy and ECLECTICISM}

There are similarities between Eclecticism and post-method pedagogy. Both Eclecticism and postmethod pedagogy advocate the effectiveness of pedagogy.

On the one hand, post-method pedagogy suggests ELT pedagogy by the local ELT practitioners or teachers. It is thought to be an alternative to the method. It proposes that in a particular socio-cultural 
context, teaching-learning pedagogy will be particular as teaching-learning goals, teachers, and learners are different. It is an opportunity to create and utilize learning opportunities. It allows teachers to modify and adjust a method. Thus, it is the proper utilization of existing teaching-learning realities.

In the same way, Eclecticism proposes to select materials by the teachers combining all good ideas, principles, and practices. For that, teachers need to consider learners' ability, and the aims of the syllabus and curriculum. It creates the opportunity for language teachers to use the techniques and activities drawn from various language teaching approaches and methods. The teachers decide what to use depending on the teaching-learning culture. Teaching styles, ideas, and practices need to be reconsidered to meet the demands and benefits of the learners. So, in the post-method era, local teachers can take the opportunity of selecting materials from several methods based on the contextual realities.

\section{Vili. General Recommendations for Making Teaching-Learning Effective}

Modified concepts of both Post-method pedagogy and Eclecticism can be useful for the Bangladeshi context. Chaudhury and Karim (2014) properly remark, "Possibly the implementation of more eclectic approaches or combinations of methods may be appropriate in Bangladeshi context." For blending different approaches and methods the following steps can be taken.

a. Taking the whole country as a particular context, a group of nationally selected teachers will select necessary elements from all methods and approaches. In our context, all teachers are not equally skilled. So it will be wise to hand over the responsibilities to a group of teachers.

b. For designing pedagogy, selected teachers will consider the needs of the learners and existing contextual realities of Bangladesh. According to Popova (2001), a teacher has to adopt such a method that will work for most of the learners (p.4). Therefore, a teacher has to focus on the students' necessity while selecting pedagogical items.

c. Following the Grammar Translation Method teaching new words and translation can be reintroduced for our context. At a lower level, grammatical rules can be taught. Furthermore, influential role of teachers will be helpful for our context as the psychological buildup of the learners suggests dependency on seniors.

d. Following Communicative Language Teaching overall classroom discussion or activities under teachers' control instead of group work and pair work can be effective. In the higher classes, teachers' role as an advisor and authentic materials should be practised. In the syllabus, tasks of listening and speaking skills in a limited scale are to be included for higher classes. Besides following the Audiolingual method, drill can be practiced to a limited scale.

e. Following the Direct Method practising new words in full sentences will develop communicative ability. Principles of teaching everyday vocabulary can be taught through demonstration, concrete objects, and pantomime.

f. Following the concepts of the Bilingual Method, both the target language and mother tongue can be allowed. For the initial level, mother tongue can be permitted, but at the advanced level, teachers should encourage students to use the target language more and more.

g. Following the principles of Suggestopedia, the selected group of teachers need to put much emphasis on learners' mental aspects and removing psychological barriers as fear, nervousness, tension, frustration, etc. Learners can be offered a cheerful, bright, colorful, and non-threatening classroom environment that will be much helpful in Bangladesh.

h. Following the Structural Situational Approach, a careful selection, gradation and presentation of vocabulary items, and structure through situationbased activities can be fruitful.

i. Following the Silent Way concept of gesture and physical response can grab students' attention at a lower level in some cases. Again, an innovative way of classroom organization may be welcomed.

j. The selected teachers should modify and adjust any practices from any methods for the Bangladeshi context if necessary. In some cases, they will innovate some new procedures.

\section{Conclusion}

Thus taking aspects from several methods and giving priority to the learners' needs, the selected group of teachers can construct appropriate pedagogy for Bangladesh. Tasks and content-based items can be given priority. To make the teaching-learning effective in the Bangladeshi context, language practitioners can follow this process as no single method or approach is sufficient for our context. The socio-cultural realities of Bangladesh are different. So, it is best to construct pedagogy by the local ELT practitioners considering practical aspects. Therefore, the concepts of Eclecticism can strongly be advocated, which combines the best features of each approach.

\section{RÉFÉRENCES}

1. Al-Hamash, I. K. and H. Younis .1985. Principles and Techniques of Teaching English as a Second Language. Al-shaab Press. 
2. Bell, D. M. (2007). Do teachers think that methods are dead? ELT journal, 61(2), 135-143.

3. Cattell, Allisan G. 2009. Re-evaluating Communicative Language Teaching: Wittgenstes and Postmethod Pedagogy. M.A. Thesis presented to the University of Waterloo in German. Waterloo, Canada.

4. Chaudhury, T. A. and M. Z. Karim. 2014. CLT Approach in developing English reading skills in tertiary levels in Bangladesh. Asian Journal of Education and e-Learning. Vol-2, Issue-01.

5. English in Action. 2009. An Assessment of Spoken English Competence among School Students, T Teachers and Adults in Bangladesh. Baseline Study Report. Retrieved from: http//www. eiabd.com./ eiabaseline/Baseline\%20study-1.pdf

6. Larsen-Freeman, D. 2000. Techniques and Principles in Language Teaching (2nd ed.). Oxford: Oxford University Press.

7. Kumar, C. P. 2013. The eclectic method-theory and its application to the learning of English. International Journal of Scientific and Research Publications, 3(6).

8. Kumaravadivelu, B. 1994. The postmethod condition: (E) merging strategies for second/ foreign language teaching. TESOL Quarterly, 28 (1), 27-48.

9. Kumaravadivelu, B. 2001. Toward a postmethod pedagogy. TESOL Quarterly, 35, 537-560.

10. Palmer, H.E. 1964. The Principles of Language Study. London: Oxford University Press.

11. Popova, D. 2001. Eclecticism in Foreign Language Teaching. Greta: Canada 9(2), 35-37.

12. Richards, J.C., \& Rodgers, T.S. 2001. Approaches and methods in language teaching. Cambridge: Cambridge University Press.

13. Rivers, W. 2018. Teaching Foreign Language Skills. (2nd ed.). Chicago: University of Chicago Press.

14. Rivers, W. 1986. The Psychologist and the Foreign Language Teacher. Chicago and London: University of Chicago Press.

15. Sato, K., \& Kleinsasser, R. C. 1999. Communicative language teaching (CLT): Practical understandings. The Modern Language Journal, 83(4), 494-517.

16. Stern, H. H. 1983. Fundamental Concepts of Language Teaching. Oxford: Oxford University Press.

17. Wali, N.H. (2009). Eclecticism and Language Learning. Al- Fatih Journal. No .39. Diyala University College of Basic Education. 